\title{
Efektivitas Etelcalcitide terhadap Hiperparatiroidisme Sekunder \\ Pada Pasien Gagal Ginjal Kronik
}

\section{Effectiveness of Etelcalcitide on Secondary Hyperparathyroidism in Patients Chronic Kidney Failure}

\author{
Sakura Muhammad Tola \\ Departemen Farmakologi Fakultas Kedokteran Universitas YARSI, Jakarta \\ Korespondensi: Email: sakura.muhammad@yarsi.ac.id
}

\begin{abstract}
Secondary hyperparathyroidism (SHPT) is a frequently occurring severe complication of advanced kidney disease. Its clinical consequences include extraskeletal vascular and valvular calcifications, changes in bone metabolism resulting in renal osteodystrophy, and an increased risk of cardiovascular morbidity and mortality. Calcimimetics are a cornerstone of parathyroid hormone (PTH)-lowering therapy, as confirmed by the recently updated 2017 Kidney Disease: Improving Global Outcomes chronic kidney disease - mineral and bone disorder clinical practice guidelines. Contrary to calcitriol or other vitamin D-receptor activators, calcimimetics reduce PTH without increasing serumcalcium, phosphorus, or FGF23 levels. Etelcalcetide is a new second-generation calcimimetic that has been approved for the treatment of sHPT in adult hemodialysis patients. Whereas the first-generation calcimimetic cinacalcet is taken orally once daily, etelcalcetide is given intravenously thrice weekly at the end of the hemodialysis session. Apart from improving drug adherence, etelcalcetide has proven to be more effective in lowering PTH when compared to cinacalcet, with an acceptable and comparable safety profile. The hope for better gastrointestinal tolerance with intravenous administration is no true, as etelcalcetide isn't significantly mitigate the adverse gastrointestinal effects associated with cinacalcet. Enhanced adherence and strong reductions in PTH, phosphorus, and FGF23 can set the stage for a future large randomized controlled trial to demonstrate that improve biochemical control of mineral metabolism with etelcalcetide in hemodialysis patients translates into cardiovascular and survival benefits and better health-related quality of life.
\end{abstract}

Keyword: Etelcalcetide calcimimetic Secondary hyperparathyroidism

\section{Pendahuluan}

Penyakit ginjal kronik merupakan masalah kesehatan global yang cukup serius. Kondisi ini merupakan suatu kondisi kronik epidemik yang menggantikan posisi malnutrisi dan infeksi sebagai penyebab tertinggi mortalitas selama abad ke-20. Tingkat kematian berdasarkan usia akibat penyakit ginjal kronik makin meningkat selama 23 tahun terakhir. Peningkatan insiden penyakit ginjal kronik dan 
gagal ginjal kronik yang membutuhkan terapi transplantasi ginjal serta tingginya angka mortalitas dan morbiditas gangguan kardiovaskuler turut menyebabkan epidemik penyakit ginjal kronik di seluruh dunia (Abd ElHafeez et al., 2018)

Beberapa faktor resiko timbulnya penyakit ginjal kronik adalah diabetes, hipertensi dan obesitas. Diabetes dan hipertensi menyebabkan nefropati diabetik dan hipertensif. Kedua kondisi ini menyebabkan angka kejadian gagal ginjal tahap akhir meningkat di usia sekitar 50 tahun atau lebih sedang glomerulonephritis dan penyakit genetik menjadi penyebab utama meningkatnya angka kejadian gagal ginjal tahap akhir pada usia dibawah 50 tahun (Alashek et al., 2012)

Komplikasi gagal ginjal kronik bervariasi antara lain anemia, hipertensi, asidosis serta gangguan metabolisme mineral dan tulang, diantaranya 1) gangguan metabolisme kalsium, fosfat dan vitamin $D, 2$ ) gangguan tulang dalam hal turnover, mineralisasi, volume, pertumbuhan dan kekuatan, 3) kalsifikasi vaskuler dan jaringan lunak. Hiperparatiroidisme sekunder merupakan kondisi klinis akibat gangguan metabolisme mineral tulang pada pasien penyakit ginjal kronik. Hiperparatiroidisme sekunder terjadi akibat gangguan ekskresi fosfat yang menyebabkan kadar fosfat meningkat dalam darah serta akibat penurunan kadar vitamin D3 yang disebabkan oleh ketidakmampuan ginjal memetabolisme vitamin D3 karena berkurangnya massa ginjal (Abd ElHafeez et al., 2018, Cunningham et al., 2011)

\section{Patogenesis Hiperparatiroidisme Sekunder}

Hiperparatiroidisme sekunder terjadi karena penumpukan fosfat dalam tubuh akibat terhambatnya pengeluaran fosfat melalui ginjal, serta penurunan kadar kalsitriol akibat berkurangnya massa ginjal pada gagal ginjal kronik. Peningkatan kadar fosfat dalam darah, yang sebagian besar dalam bentuk fosfat inorganik, mengakibatkan tiga hal yaitu: 1) hipokalsemia sebagai akibat dari gangguan fisikokimiawi, 2) secara langsung merangsang kelenjar paratiroid untuk mensekresikan hormon paratiroid (Parathyroid hormone/PTH), 3) meningkatkan pelepasan fibroblast growth factor 23 (FGF 23) oleh osteosit dan osteoblast tulang skelet. Selanjutnya FGF 23 ini menstimulus kelenjar paratiroid untuk mensekresikan PTH. Peningkatan kadar FGF 23 juga akan menghambat $\mathrm{Na}-\mathrm{Pi}$ co-transport di ginjal dan mengakibatkan fosfaturia, menghambat $1-\alpha$ vit D3 hidroksilase yang akan mengakibatkan penghambatan resorbsi fosfat inorganik $(\mathrm{Pi})$ dan kalsium di saluran cerna (Cunningham et al., 2011. Cannata-Andia 2008). Sementara itu, kondisi hipokalsemia mengakibatkan peningkatan aktifitas calcium sensing receptor (CaSR) pada kelenjar paratiroid, yang selanjutnya mengakibatkan sintesis PTH melalui transkripsi gen pre/pro serta meningkatkan proliferasi sel kelenjar paratiroid yang pada akhirnya akan memicu peningkatan sekresi PTH. Disisi lain, hipokalsitriolemia akan menstimulus reseptor vitamin $\mathrm{D}$ (vitamin $D$ receptor,VDR) yang selanjutnya akan menstimulus kelenjar paratiroid mensekresikan PTH. Hasil akhir dari semua proses di atas adalah peningkatan sekresi PTH yang dikenal dengan "hiperparatiroidisme sekunder atau secondary hyperparathyroidism".

Patogenesis hiperparatiroidisme sekunder dapat dilihat pada Gambar 1.

Hiperfosfatemia dapat meng-akibatkan hipokalsemia akibat gangguan keseimbangan fisikokimiawi. Peningkatan kadar fosfat akan 
selalu dikompensasi dengan penurunan kadar kalsium tetapi peningkatan kadar ion kalsium tidak dikompensasi dengan penurunan fosfat sehingga terbentuk garam kalsium fosfat (CaPO4) yang mudah mengendap dan mengakibatkan kalsifikasi (Cunningham et al., 2011; Cannata-Andia, 2008).

\section{Farmakologi Etelcalcitide}

Etelcalcitide merupakan suatu kalsimimetik yang sifatnya sebagai aktivator allosterik dan secara spesifik meningkatkan sensitivitas CaSR terhadap kalsium ekstraseluler. Etelcalcitide dapat mengaktifkan jalur sinyal CaSR pada kelenjar paratiroid. Aktivasi reseptor CaSR terjadi melalui pembentukan jembatan disulfida antara asam amino D-cysteine etelcalcetide dengan asam amino L-cysteine CaSR. Ikatan langsung obat ini pada domain ekstraseluler CaSR akan mengaktifkan reseptor pada posisi berbeda dari tempat aktivasi kalsium. Reseptor ini banyak ditemukan di sel parietal kelenjar paratiroid dan beberapa di tubulus dan gromerulus ginjal, sel langerhans pancreas, sel glanduler usus halus dan sel parafolikuler kelenjar tiroid (European medicine agency 2016). Etelcalcitide hanya bekerja pada reseptor CaSR, tidak menghambat atau menginduksi ikatan ligand reseptor GPCR III. Melalui ikatan dengan reseptor CaSR, etelcalcitide dapat mempertahankan homeostatis kalsium dalam tubuh, juga dapat mengurangi produksi hormon paratiroid, mencegah kalsifikasi jaringan lunak pada aorta dan jantung, mencegah hiperplasia kelenjar paratiroid serta mengurangi gangguan metabolisme mineral tulang di ginjal. (Cozzolino et al., 2017; European medicine Agency, 2016; Eidman et al., 2018).

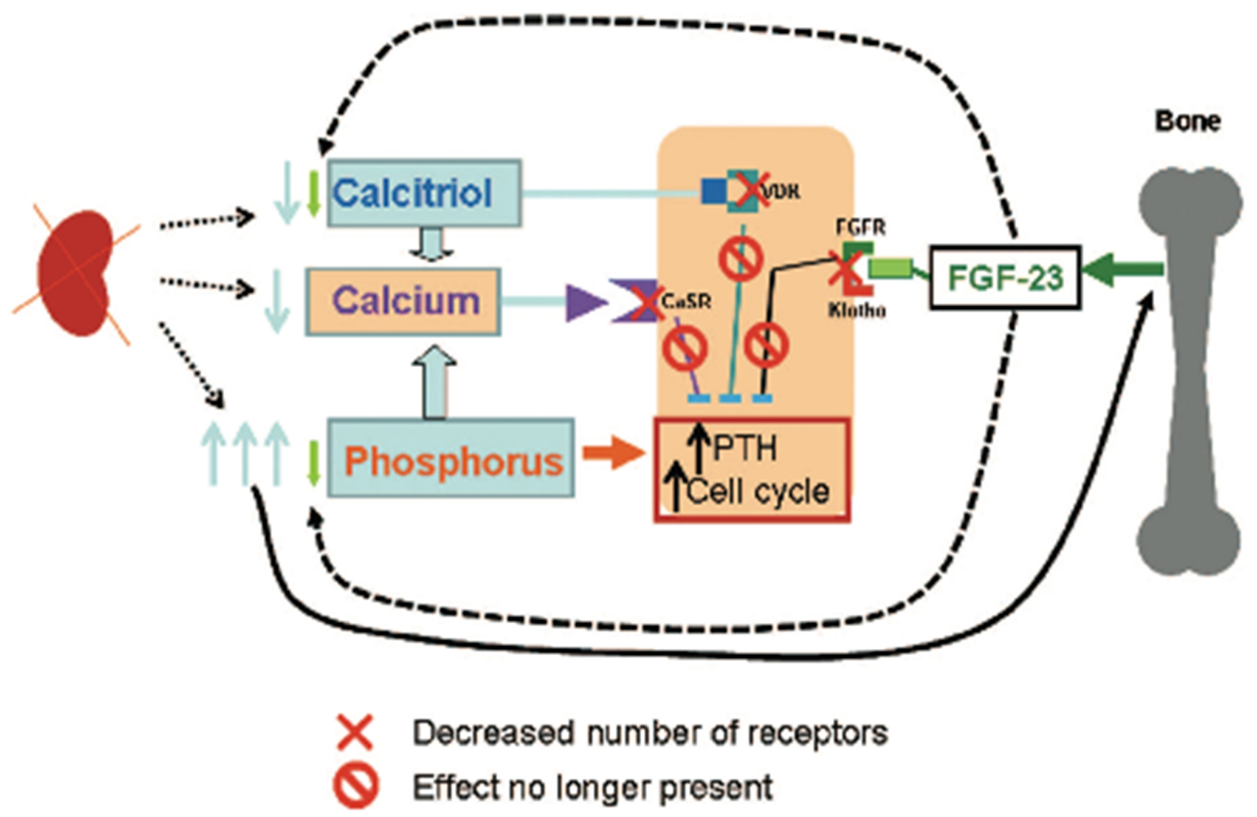

Gambar 1. Pathogenesis hiperparatiroidisme sekunder.

Pemberian etelcalcitide secara intra vena dengan dosis yang berbeda menunjukkan kadar plasma yang berbeda pula. Volume distribusi bervariasi ke berbagai jaringan seperti ginjal, hati, kartilago, plat epifise, lien dan sumsum tulang serta limfonodus. Sekitar $40-70 \%$ 
etelcalcitide terikat dengan protein plasma albumin. Etelcalcitide mengalami metabolisme di hati melalui penggantian molekul L-cysteine dengan disulfida sedang molekul D-asam amino lainnya tidak berubah. Metabolisme obat ini tidak melibatkan golongan enzim sitokrom hati sehingga tidak terjadi interaksi obat terhadap obat lain yang dimetabolisme oleh enzim sitokrom. Hasil metabolisme etelcalcitide berupa serum albumin peptide conjugate (SAPC). Ekskresi terutama melalui ginjal dengan laju ekskresi yang bervariasi bergantung pada fungsi ginjal. (European medicine Agency, 2016,; Eidman et al., 2018).

Pada pasien hiperparatiroidisme sekunder akibat gagal ginjal kronik yang menjalani hemodialisis menunjukkan waktu paruh eliminasi sekitar 2-120 jam. Etelcalcitide sebaiknya diberikan setelah hemodialisis untuk mencegah eliminasi fraksi dosis obat. Efek samping akibat pemberian etelcalcitide antara lain berkurangnya massa tymus dan lien namun massa kelenjar adrenal meningkat. Pada percobaan in vitro juga didapatkan pemanjangan interval QT yang diinduksi oleh penurunan kadar kalsium terutama pada pasien yang memiliki resiko untuk mengalami pemanjangan interval QT. (Fielden, 2016). Pemberian $5 \mathrm{mg}$ etelcalcitide pada pasien gagal ginjal kronik yang menjalani hemodialisis menunjukkan efek penurunan kadar PTH. Kadar steady state etelcalcitide tercapai setelah 4 minggu pemberian obat ini dengan titrasi dosis tiap 4 minggu. (European medicine Agency, 2016; Eidman et al., 2018).

\section{Pengaruh Etelcalcitide Hiperparatirodisme Sekunder}

terhadap

Beberapa studi menunjukkan pengaruh etelcalcitide terhadap sekunder. Study randomized, double-blind, placebo-controlled, parallel-group study yang dilakukan oleh Masafumi dkk dengan outcome primer berupa jumlah pasien yang mengalami penurunan kadar intact parathyroid hormone (iPTH) serum mencapai target yang ditetapkan oleh Japanese Society for Dialysis Therapy (60$240 \mathrm{pg} / \mathrm{mL}$ ). Adapun outcome sekundernya adalah jumlah pasien yang mengalami penurunan kadar iPTH > 30\% dari baseline. Hasil penelitian menunjukkan jumlah pasien yang memenuhi outcome primer lebih tinggi pada kelompok etecalcetide mencapai 59\% dibandingkan placebo. Selain itu jumlah pasien yang kadar iPTH nya berkurang $>30 \%$ dari baseline lebih tinggi pada kelompok etelcalcetide dibanding placebo (76,9\%: 5,2\%) (Fukagawa et al., 2017).

Penelitian untuk menguji costeffectiveness penggunaan etelcalcetide versus cinacalcet menggunakan decision-analysis model (tanpa menghitung biaya hemodialisis) menunjukan efikasi jangka panjang etelcalcitide diekstrapolasikan dari efeknya dibandingkan cinacalcet dan plasebo terhadap penurunan kadar PTH. Cost-effectiveness etelcalcetid dapat bervariasi antara satu negara dengan negara lain tergantung pada unit biaya psesifik suatu negara, unit biaya untuk tiap kejadian atau tindakan klinik, kebijakan reimbursement dan kesediaan masyarakat untuk membayar selisih biaya perawatan. Tujuan terapi hiperparatiroidisme sekunder adalah memperbaiki kadar hormon paratiroid, kalsium dan fosfat serum. Terapi awal berupa perubahan pola diet (membatasi asupan fosfat), mengkonsumsi zat pengikat fosfat dan vitamin $D$ seperti alfakalsidol, kalsitriol atau parikalsitol. Vitamin D aktif dapat meningkatkan kadar kalsium serum. Pemberian kalsimimetik seperti 
cinacalcet kombinasi dengan pengikat fosfat dan vitamin D dapat mengurangi kadar kalsium serum. Peningkatan kadar kalsium serum dan hormon paratiroid yang terus menerus walaupun telah disertai pemberian obat pengikat fosfat atau vitamin $D$ dapat menyebabkan hiperparatiroidisme sekunder refrakter. Etelcalcetide tetap sebaiknya diberikan bahkan jauh lebih bermanfaat pada penanganan hiperparatiroidisme refrakter walaupun pasien telah menggunakan pengikat fosfat atau vitamin D (NICE guideline, 2017).

Etelcalcitide mempunyai level lebih superior dibanding cinacalcet dalam menurunkan kadar PTH dan FGF-23 pada pasien gagal ginjal kronik stadium akhir. Kadar FGF-23 umumnya meningkat pada pasien penyakit ginjal kronik dan berkaitan dengan kejadian efek samping hipertrofi ventrikel kiri dan gagal jantung. Namun demikian penggunaan etelcalcitide juga dapat menyebabkan timbulnya hipokalsemia. Data yang ada menunjukkan hipokalsemia cenderung terjadi pada permulaan terapi pada pasien yang memiliki kadar PTH tertinggi. Kondisi hipokalsemia ini bahkan dapat berlangsung selama 10-12 minggu. Efek hipokalsemia ini dapat terjadi walaupun pada pasien telah diberikan kalsium oral atau analog vitamin D aktif dan terdapat peningkatan kadar kalsium dialisat setelah dialisis (Pereira et al., 2018).

Ketersediaan dan indikasi penggunaan etelcalcitide dapat menjadi salah satu pilihan tata laksana gangguan mineralisasi tulang yang akibat penyakit ginjal kronik. Ketersediaan etelcalcitide dalam bentuk obat parenteral intravena menyebabkan obat ini dapat diberikan bersama dengan regimen pengobatan pasien lainnya walaupun pasien mengalami gangguan karena penyakitnya (Patel et al., 2018). Dari segi biaya penelitian yang mengkaji cost effectiveness etelcalcitide juga menunjukkan The incremental cost-effectiveness ratio (ICER) etelcalcetide dibandingkan cinacalcet adalah $£ 14,778$ per quality-adjusted life-year (QALY). Namun perhitungan ICER ini relatif belum terlalu signifikan oleh karena kurangnya data penggunaan dan data evaluasi ekonomi etelcalcitide (Rose et al., 2018).

Penelitian multisenter, open label, tentang efek jangka panjang penggunaan etelcalcetide telah dilakukan pada 191 pasien hemodialisis di Jepang dengan nilai baseline PTH adalah $>240$ $\mathrm{pg} / \mathrm{mL}$. Pasien diberikan etelcalcetide $3 \mathrm{x}$ seminggu dengan dosis awal $5 \mathrm{mg}$ yang kemudian dititrasi hingga dosis 2,5-15 mg untuk mencapai kadar PTH 60-240 pg/mL. Dosis rerata di kurangi secara bertahap selama dosis akhir sekitar 5,5 mg. Hasil penelitian menunjukkan sekitar $87,5 \%$ pasien dapat mencapai penurunan kadar PTH sesuai target dengan rerata kadar PTH adalah $157 \mathrm{pg} / \mathrm{mL}$. $4,7 \%$ pasien mengalami mual, 9,5\% pasien mengalami muntah, dan $1,1 \%$ pasien mengalami hipokalsemia simptomatik (Shigematsu, et al., 2018).

\section{Cost-Effectiveness Etelcalcitide untuk Tata Laksana Hiperparatirodisme Sekunder}

$\begin{array}{crr}\text { Biaya } & \text { pengobatan } & \text { dengan } \\ \text { hiperparatirodisme } & \text { sekunder } & \text { dengan } \\ \text { menggunakan cinacalcet atau } & \text { etelcalcetide }\end{array}$
bersifat dose dependent oleh karena setiap obat dititrasi berdasarkan respon pasien dan kondisi klinik pasien. Penggunaan jangka panjang cinacalcet suatu kalsimimetik pendahulu etelcalcitide yang diberikan dengan dosis awal $30 \mathrm{mg}$ tablet oral menunjukkan biaya rerata keseluruhan (the average wholesale price/AWP) adalah $\$ 968$ untuk 30 paket berisi tablet $30 \mathrm{mg}$. Dosis pemeliharaan pasien yang diukur 
berdasarkan kadar PTH selama pengobatan bervariasi antara 30-180 mg sekali sehari sehingga perhitungan biaya keseluruhan cinacalcet dapat mencapai sekitar $\$ 5,808$ untuk penggunaan selama sekitar 1 bulan. Sedangkan biaya keseluruhan penggunaan etelcalcetide yang diberikan secara intravena dengan dosis 5 $\mathrm{mg}$ tiga kali seminggu oleh petugas medis sesaat setelah hemodialysis adalah sekitar \$ 589. Dosis pemeliharaan etelcalcitide pasien berdasarkan kadar PTH dan kalsium serum dapat lebih rendah $2.5 \mathrm{mg}$ tiga kali seminggu (AWP selama seminggu \$294) atau lebih tinggi hingga $15 \mathrm{mg}$ tiga kali seminggu (AWP selama seminggu \$1,765) (Patel et al., 2018). Biaya penggunaan etelcalcetide, cinacalcet, pengikat fosfat dan vitamin $D$ sterol dihitung berdasarkan jumlah rerata dosis per hari yang digunakan. Biaya perawatan dihitung berdasarkan biaya rerata tindakan elektif atau non elektif selama proses hemodialisis. Berdasarkan sebuah patient access scheme (PAS) yang review menggunakan Patient Access Scheme Assessment Group (PASAG), case incremental cost-effectiveness ratio (ICER) dan analisis sensitivitas etelcalcitide menunjukkan biaya penggunaan etelcalcitide lebih rendah dari pada kalsimimetik pendahulunya yaitu cinacalcet (Rose et al., 2018, Scottish Medicines Consortium, 2017).

\section{Simpulan}

1. Generasi kedua kalsimimetik etelcalcetide efektif mengurangi kadar PTH, fosfor, kalsium dan FGF23 pada pasien yang menjalani hemodialisis

2. Pemberian secara intravena etelcalcitide sesaat setelah hemodialisis dapat mencegah eliminasi fraksi dosis obat dan memperbaiki manjemen sHPT dibanding terapi standar
3. Efek samping yang dapat timbul pada pemberian eletcalcitide adalah pemanjangan interval QT terutama pada pasien yang memiliki faktor resiko.

\section{Daftar Pustaka}

Abd ElHafeez, S, Bolignano, D, D’Arrigo, G, Dounousi,E, Tripepi, G, Zoccali, C. 2018. Prevalence and burden of chronic kidney disease among the general population and high-risk groups in Africa: a systematic review. BMJ Open 2018;8:e015069. doi:10.1136/bmjopen-2016-015069.

Alashek WA, McIntyre CW, Taal MW. Epidemiology and aetiology of dialysistreated end-stage kidney disease in Libya. BMC Nephrol 2012;13:33.

Cunningham J, Locatelli $F$, Rodriguez $M$. Secondary Hyperparathyroidism: Pathogenesis, Disease Progression, and Therapeutic Options. Clinical Journal of the American Society of Nephrology. 2011;6:913-21.

Cannata-Andia JB, Carrera F. The Pathophysiology of Secondary Hyperparathyroidism and the Consequences of Uncontrolled Mineral Metabolism in Chronic Kidney Disease: The Role of COSMOS. NDT Plus. 2008 Jan; 1(Suppl 1): i2-i6.

Cozzolino M, Galassi A, Conte F, Mangano M, Di Lullo L, Bellasi A. Treatment of secondary hyperparathyroidism: the clinical utility of etelcalcetide. Therapeutics and Clinical Risk Management 2017;13:679-89.

European medicine Agency. Assessment report PARSABIV. International non-proprietary name: etelcalcetide. European Medicines Agency 2016;page 1-98. 
Eidman KE, Wetmore JB. Managing hyperparathyroidism in hemodialysis: role of etelcalcetide. International Journal of Nephrology and Renovascular Disease 2018;11: 69-80.

Fukagawa M, Yokoyama K, Shigematsu T, Akiba T, Fujii A, Kuramoto $T$, et al. A phase 3, multicentre, randomized, double-blind, placebo-controlled, parallel-group study to evaluate the efficacy and safety of etelcalcetide (ONO-5163/AMG 416), a novel intravenous calcimimetic, for secondary hyperparathyroidism in Japanese haemodialysis patients. Nephrol Dial Transplant 2017;32:1723-30.

Friedl C, Zitt E. Role of etelcalcetide in the management of secondary hyperparathyroidism in hemodialysis patients: a review on current data and place in therapy. Dovepress 2018; 2018(12):1589-98.

NICE guideline. Etelcalcetide for treating secondary hyperparathyroidism. Technology appraisal guidance Published: 28 June 2017. nice.org.uk/guidance/ta448. Page 4-22.

Pereira L, Meng C, Marquis D, Frazao JM. Old and new calcimimetics for treatment of secondary hyperparathyroidism: impact on biochemical and relevant clinical outcomes. Clinical Kidney Journal 2018;11(1): 80-8.

Patel J, Bridgeman MB. Etelcalcetide (Parsabiv) for Secondary Hyperparathyroidism in Adults With Chronic Kidney Disease on Hemodialysis. Pharmacy 7 Therapeutics 2018; 43(7):396-9.

Rose M, Shepherd J, Harris P, Pickett K, Lord J. Etelcalcetide for Treating Secondary Hyperparathyroidism: An Evidence Review Group Evaluation of a NICE Single Technology Appraisal. Pharmacoeconomics;2018:36(11):12991308. doi: 10.1007/s40273-018-0661-2.

Shigematsu T, Fukagawa M, Yokoyama K, Akiba $T$, Fujii A, Odani $M$, et al. Long term effect of etelcalcitide as intravenous calcimimetic therapy in hemodialysis patients with secondary hyperparathyroidism. Clinical and Experimental Nephrology 2018; 22(2):426-36.

Scottish Medicines Consortium. etelcalcetide $2.5 \mathrm{mg}, 5 \mathrm{mg}$, and $10 \mathrm{mg}$ solution for injection SMC No 1262/17. NHS Scotland. www. Scottishmedicines.org.uk. Published 11 September 2017. Page 1-12. 